Sains Malaysiana 50(8)(2021): 2319-2328

http://doi.org/10.17576/jsm-2021-5008-15

\title{
Comparing the Effects of Alpha-Tocopherol and Tocotrienol Isomers on Osteoblasts hFOB 1.19 Cultured on Bovine Bone Scaffold
}

(Perbandingan Kesan Isomer Alfa-Tokoferol dan Tokotrienol pada Osteoblas hFOB 1.19 yang Dikultur atas Perancah Tulang Bovin)

\author{
Nur Farhana Mohd Fozi, James Jam Jolly, Chua Kien Hui, Ekram Alias, Chin KoK Yong \& Ima NiRWANA \\ SOELAIMAN*
}

\section{ABSTRACT}

Tocotrienol mixtures have been shown to exert anabolic actions on the skeletal system in animal studies, but it is unclear which tocotrienol isomer shows the most prominent effects. This study aims to investigate the most active tocotrienol isomers using hFOB 1.19 human osteoblasts cultured on a bovine bone scaffold. The bovine trabecular bone was sectioned, demineralised and freeze-dried to form the scaffold. hFOB 1.19 osteoblasts were cultured on the bone scaffolds in humidified condition at $37{ }^{\circ} \mathrm{C}$ and $5 \%$ carbon dioxide with vitamin E isomers (alpha-, beta-, gamma-, delta-tocotrienol and alpha-tocopherol). The cell differentiation capacity of tocotrienol isomers was investigated through morphological observation, alkaline phosphatase (ALP) activity and osteocalcin expression. Changes in the bone scaffolds were determined using histomorphometry methods. Osteoblast culture treated with gamma-and delta-tocotrienols showed a significant increase in ALP activity and osteocalcin expression. Bone structural histomorphometry analysis showed that bone scaffolds treated with gamma- and delta-tocotrienol showed significant increases in bone volume and trabecular thickness. In conclusion, gamma- and delta-tocotrienol show the most prominent bone anabolic effects by increasing osteoblast differentiation and enhancing bone microstructure.

Keywords: Bone; osteoblast; osteoporosis; tocopherol; tocotrienol

\section{ABSTRAK}

Campuran tokotrienol telah terbukti memberi kesan anabolik kepada sistem rangka di dalam kajian haiwan, tetapi isomer tokotrienol yang paling berkesan belum dikenal pasti. Kajian ini bertujuan mengkaji isomer tokotrienol yang paling aktif dengan menggunakan sel osteoblas manusia hFOB 1.19 yang dikultur atas tulang perancah lembu. Tulang trabekular lembu dipotong dan dikering-beku untuk membentuk perancah. Sel osteoblas hFOB 1.19 dikulturkan di atas perancah tulang dalam kelembapan $37{ }^{\circ} \mathrm{C}$ dan $5 \%$ karbon dioksida bersama isomer vitamin E (alfa-tokotrienol, beta-tokotrienol, gamma-tokotrienol, delta-tocotrienol dan alfa-tokoferol). Kapasiti pembezaan sel isomer tokotrienol dikaji melalui pemerhatian morfologi, aktiviti alkalin phosphatase (ALP) dan ekspresi osteokalsin. Perubahan struktur tulang ditentukan dengan kaedah histomorfometri. Sel osteoblas yag dirawat dengan gamma-dan delta-tokotrienol menunjukkan peningkatan aktiviti ALP dan ekspresi osteokalsin yang ketara. Tulang perancah yang dirawat dengan gamma-tokotrienol dan delta-tokotrienol mempunyai peningkatan isi padu serta ketebalan trabekular yang ketara melalui analisis histomorfometri. Secara kesimpulannya, gamma-dan delta-tokotrienol menunjukkan kesan anabolik tulang yang paling ketara dengan meningkatkan pembezaan osteoblas dan struktur seni tulang.

Kata kunci: Osteoblas; osteoporosis; tokoferol; tokotrienol; tulang

\section{INTRODUCTION}

Osteoporosis is characterised by a reduction in bone mass and increased susceptibility to fractures (Roux $\&$ Orcel 2000). The current treatment of osteoporosis consists of lifestyle changes and pharmacological therapy to prevent fragility fractures (Pavone et al. 2017). A wide range of pharmacological modalities, including bisphosphonates, teriparatide, denosumab, and oestrogen 
receptor modulators, are currently used to manage osteoporosis. Despite their effectiveness, these agents are not free from undesirable side effects (Cejka et al. 2008; Finkelstein et al. 2010). Therefore, the search for effective and safe agents to treat osteoporosis is ongoing.

Several studies demonstrated that vitamin E, especially tocotrienol, attenuates bone resorption and enhances bone formation in various animal models of osteoporosis (Chin \& Soelaiman 2015; Feresin et al. 2013; Shen et al. 2017; Shuid et al. 2010). Vitamin E is an essential lipophilic vitamin with good antioxidant activity. Natural vitamin E derived from plant seeds contains a mixture of tocotrienols and tocopherols (Chun et al. 2006). They can further be divided into four different isomers, which are alpha-, beta-, gamma-, and delta-tocotrienol, characterised by different numbers and position of the methyl group on the chromanol ring (Wong et al. 2020). The abundance of each vitamin $E$ isomers in plant mixtures varies. In general, alpha-tocopherol is the most abundant vitamin $\mathrm{E}$ isomer in nature (Sen et al. 2010). Tocotrienols are the unsaturated members of vitamin E, which are found primarily in palm oil (predominantly gamma-tocotrienol), rice bran (equal ratio of tocopherol and tocotrienol) and annatto bean (predominantly deltatocotrienol) (Daud et al. 2013).

The effects of vitamin $\mathrm{E}$ in preventing osteoporosis have been actively investigated. Studies using animal models of osteoporosis showed that vitamin E, especially tocotrienol mixtures, exerts beneficial skeletal effects by preserving bone mineral density, microstructure, and biomechanical strength (Chin \& Soelaiman 2019, 2015; Shen et al. 2017). The skeletal benefits of vitamin E are contributed by its antioxidant and anti-inflammatory activities (Wong et al. 2019). Tocotrienol also possesses mevalonate suppressive activities, which are not shared by tocopherols (Vasanthi et al. 2012). A study by Chin and Soelaiman (2014) showed that the skeletal effects of annatto tocotrienol mixture are anabolic, whereby it increases many osteoblast-related genes but not the osteoclast-related genes. Many studies used animal models to demonstrate the action of vitamin E mixture derived from palm and annatto in preventing bone loss (Chin \& Soelaiman 2015). So far, a direct comparison of the skeletal anabolic effects among vitamin $\mathrm{E}$ isomers has not been performed.

Most of the in vitro studies on tocotrienols used twodimensional osteoblast culture (Wan Hasan et al. 2020, 2018), which may not represent the three-dimensional nature of bone. Thus, it may prevent accurate interpretation of the skeletal effects of tocotrienol observed in animal studies. Three-dimensional (3D) scaffold has been commonly used to investigate cell behaviour and drug delivery (Chiu et al. 2010; Eiselt et al. 2000). The scaffold acts as a template for tissue formation. It is seeded with cells and subjected to growth factors or biophysical stimuli to promote cell growth (Martin et al. 2004). The ideal scaffold should mimic the natural extracellular matrix (ECM) to support cell attachment, proliferation, and differentiation (Motamedian et al. 2015). In our study, the native bovine bone scaffold was used because it mimics the natural environment of bone tissue for cell growth and differentiation. This 3D culture model could be used to screen drugs which affect the bone.

The present study aims to compare the effects of alpha-tocopherol and individual tocotrienol isomers on proliferation and adhesion of osteoblasts on the bovine bone scaffold, and their ability to alter the microstructure of the scaffold. A 3D bone culture using a native bovine bone scaffold was designed to mimic the biological microenvironment of bone tissue. The results from this study could validate the most active isomers of tocotrienol, leading to optimization of tocotrienol as a pharmacological agent to prevent osteoporosis and its complications.

\section{Materials AND MEthods}

\section{BONE SCAFFOLD PREPARATION}

The processing of bone scaffolds was modified from procedures by Shahabipour et al. (2013). The bone grafts were prepared from trabecular bones harvested from bovine femurs obtained from a local butcher. The trabecular bones were sectioned into $10 \mathrm{~mm} \times 10 \mathrm{~mm} \times 5 \mathrm{~mm}$ blocks using a bone saw (PrimeHub W210CA Stainless Steel Meat Bone Saw Machine, China). The fatty bone marrow was removed by immersion in $100 \%$ ethyl alcohol for $4 \mathrm{~h}$. Trabecular bones were demineralised by using 0.6 $\mathrm{N}$ hydrochloric acid for 3 days at room temperature. Following demineralization, the scaffolds were rinsed extensively in sodium phosphate buffer to remove the residual acid. The demineralised bones were refrozen for 2 weeks. The bone grafts were then freeze-dried using a freeze-drier (Labconco, Kansas City, USA) for 3 days. Subsequently, the bone scaffolds were autoclaved and stored in air-tight glass containers. 


\section{OSTEOBLAST CULTURE}

hFOB 1.19 human osteoblasts cells (Product code: CRL11372, American Type Culture Collection, Manassas, USA) were cultured in Dulbecco's Modified Eagle's Medium (DMEM) (Thermos Fisher Scientific, New York, USA)/Ham's Nutrient Mixture F12 (Sigma Aldrich, St Louis, USA) in a ratio of 1:1 and supplemented with $10 \%$ fetal bovine serum (FBS) (Thermos Fisher Scientific, New York, USA) and 1\% antibiotic-antifungal agent (Thermos Fisher Scientific, New York, USA) in humidified condition at $37^{\circ} \mathrm{C}$ and $5 \%$ carbon dioxide $\left(\mathrm{CO}_{2}\right)$ (Abdullah et al. 2018). Cells were seeded and cultured in a $75 \mathrm{~cm}^{2}$ tissue culture flask until a sufficient number of cells was obtained. The medium was changed every 3 days under aseptic conditions. After reaching 90\% confluency, the cells were passaged (P1) until P10. The hFOB 1.19 cells were cultured on tissue culture plastic for 3 days before being transferred to the bone scaffolds.

\section{TREATMENT OF TOCOTRIENOL ISOMERS}

Tocotrienol isomers were a gift from American River Nutrition (Hadley, USA). Tocotrienol was prepared based on a previous study with some modifications (Wan Hasan et al. 2018). The stock solution of tocotrienol and alphatocopherol $(1 \mathrm{~g} / \mathrm{mL})$ was freshly prepared in $100 \%$ ethanol in $1: 1$ ratio and kept at $-20^{\circ} \mathrm{C}$ for not more than one month. The stock solution $(25 \mathrm{uL})$ was added to 60 $\mathrm{mL}$ of FBS and incubated overnight. Subsequently, $90 \mathrm{uL}$ of differentiation media and $105 \mathrm{uL}$ of ethanol was added to the mixture. The tocotrienols and alpha-tocopherol were diluted to $100 \mathrm{nM}$ in the cell culture medium. The treatment solution was prepared freshly every 2-3 days.

\section{CELL SEEDING ONTO THE BOVINE BONE SCAFFOLD}

The cells were detached from the tissue culture flask surface with trypsin EDTA (Gibco, Grand Island, New York). The excess trypsin was deactivated with the culture media and the cells were collected by centrifugation (3000 rpm for $5 \mathrm{~min}$ ). The cell pellet was re-suspended in $3 \mathrm{~mL}$ fresh medium. After that, the cells were stained with trypan blue (Thermo Scientific, Grand Island, New York) and live cells were counted using an automated cell counter (Thermo Scientific, Grand Island, New York). Cells with fresh media containing $2 \times 10^{6}$ cells $/ \mathrm{cm}^{2}$ were seeded onto the bone scaffold (Leclerc et al. 2006). The bone scaffolds were covered with $8 \mathrm{~mL}$ of fresh media with/without vitamin $\mathrm{E}$ isomers and incubated in the $\mathrm{CO}_{2}$ incubator to allow attachment of the cells. The scaffolds were maintained at $37{ }^{\circ} \mathrm{C}$ within a humidified atmosphere of $95 \%$ air containing $5 \% \mathrm{CO}_{2}$. The culture plates were agitated every day for $15 \mathrm{~min}$ to ensure a homogenous cell distribution throughout the scaffold. The medium was changed on alternate days and collected for analysis. The experiment was repeated six times in duplicates. After 21 days, the scaffolds were removed from the culture plate to be studied microscopically.

\section{CELL VIABILITY ASSAY}

Viability of hFOB 1.19 osteoblasts after treatment was measured using MTS assay in a two-dimensional culture following the manufacturer's assay protocol (CellTiter $96{ }^{\circledR}$ Aqueous, Promega Corporation, Fitchburg, USA). The cells were exposed to individual tocotrienol isomers (alpha-, beta-, gamma- and delta-tocotrienol) and alphatocopherol at different concentrations $(1,10,100$ and $1000 \mathrm{nM})$. On day 1, 3 and 7, the cells were washed with a phosphate-buffered solution and incubated with $200 \mu \mathrm{L}$ fresh culture medium and $20 \mu \mathrm{L}$ MTS solution. They were incubated for $4 \mathrm{~h}$ in $37{ }^{\circ} \mathrm{C}$ in a humidified atmosphere with $5 \% \mathrm{CO}_{2}$. The absorbance was measured at $490 \mathrm{~nm}$ using a microplate reader (Tecan, Mannedorf, Switzerland). The mean absorbance/optical density was used to calculate the percentage of cell viability as the following: percentage of cell viability $=\left(\mathrm{A}_{\text {treatment }}-\mathrm{A}_{\text {blank }}\right) /$ $\left(\mathrm{A}_{\text {control }}-\mathrm{A}_{\text {blank }}\right) \times 100 \%$, where $\mathrm{A}=$ absorbance $)$.

\section{BIOCHEMISTRY ASSAYS}

The conditioned medium was collected on day 1 and 3 , and frozen at $-80{ }^{\circ} \mathrm{C}$ for osteocalcin measurement using a competitive enzyme-linked immunoassay kit (Elabscience, Houstan, Texas).

The ability of alkaline phosphatase to hydrolyse p-nitrophenol phosphate (pNPP) substrate (Abcam, Cambridge, UK) into yellow end product, p-nitrophenol, was used to quantify alkaline phosphatase (ALP) activity in the homogenate scaffold. ALP is expressed during the active matrix maturation phase after osteoblasts reach confluency in culture. This phase lasts for 5-15 days (Wang et al. 2012). Therefore, the scaffolds were treated with tocotrienol for 3, 7 and 15 days. At the end of each time point, the scaffold was homogenated and assayed for ALP activity using an assay kit following the manufacturer's protocol (Abcam, Cambridge, UK). 
BONE HISTOMORPHOMETRY

Structural indices of the bone scaffold, including trabecular bone volume (BV/TV), number (Tb.N), thickness (Tb.Th), and separation (Tb.Sp) were determined using standard bone histomorphometric methods (Shuid et al. 2010). The undecalcified bone scaffold was embedded in poly(methyl methacrylate) (Polyscience, Niles, USA) and sectioned into $5 \mu \mathrm{m}$ thick. The sections were stained using Von Kossa method (silver nitrate staining). Micrographs of the bone sections were taken at the magnification of $200 \times$ using a microscope (Nikon Eclipse 80i, Tokyo, Japan) connected to an Image Analyzer (Media Cybernatics Image Pro-Plus, Rockville, USA). The results of unseeded undecalcified bone scaffold (PC) were included as a comparison.

\section{STATISTICAL ANALYSIS}

Statistical analysis was performed using Statistical Package for Social Sciences version 20 (IBM, Armonk, USA). Normality of the data was assessed using ShapiroWilk test and was found to be normally distributed. For cell viability, ALP and osteocalcin assay involving a concentration $\times$ group design or time $\times$ group design, mixed-design analysis of variance (ANOVA) with small effect analysis for post hoc assessment was adopted. Oneway ANOVA with Tukey's post hoc pairwise evaluation was used to compare variables involving endpoint assessment. All data were reported in mean \pm standard error mean (SEM). A p-value of $<0.05$ was considered statistically significant.

\section{RESULTS}

\section{EFFECTS OF TOCOTRIENOL AND ALPHA-TOCOPHEROL ON CELL VIABILITY}

The optimal concentrations of vitamin $\mathrm{E}$ isomers used in the study were determined by cell viability assay. The viability of the cells did not alter within the range of 1-100 $\mathrm{nM}$ vitamin $\mathrm{E}$ isomers. Beyond $1000 \mathrm{nM}$, the viability of the osteoblasts decreased drastically (data not shown). Gamma-tocotrienol and delta-tocotrienol at 10-1000 nM were noted to increase the cell proliferation compared to other vitamin $\mathrm{E}$ isomers $(\mathrm{p}<0.05)$. The middle dose within the safe range, i.e. $100 \mathrm{nM}$, was chosen for the subsequent analysis (Figure 1).

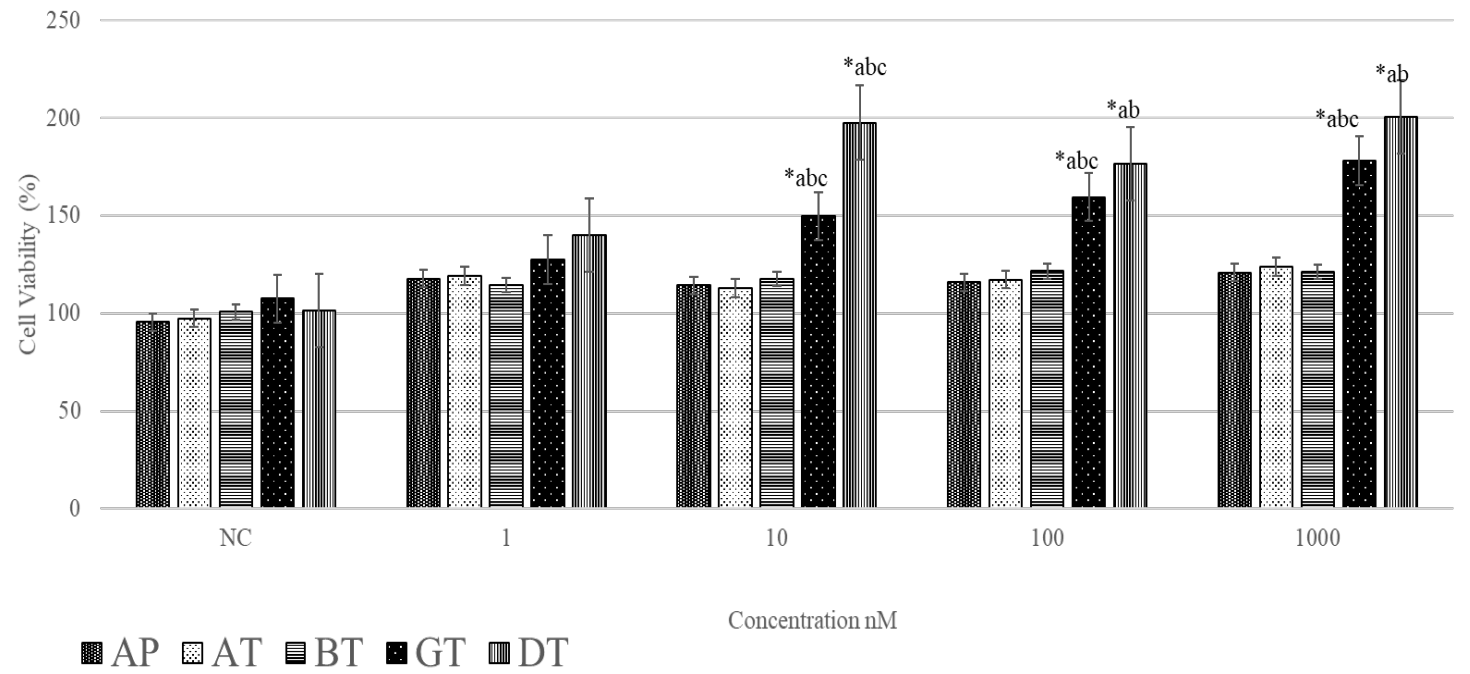

FIGURE 1. Viability of hFOB 1.19 osteoblasts treated with different concentrations of tocotrienols and alpha-tocopherol $(1,10,100$ and $100 \mathrm{nM})$ compared to the untreated cells (vehicle control, NC). ' ${ }^{*}$ ' indicates a significant difference compared with alpha-tocopherol (AP), 'a' with alpha-tocotrienol (AT), 'b' with beta-tocotrienol (BT) and 'c' with gammatocotrienol (GT) of the same treatment period. Data are presented as mean $\pm \operatorname{SEM}(n=6)$ 


\section{ALKALINE PHOSPHATASE ACTIVITY}

The ALP activity increased significantly with time regardless of treatment $(\mathrm{p}<0.05$, significance not marked in Figure 2). On day 7, the ALP activity of the alphatocopherol group was significantly higher compared to alpha- and beta-tocotrienol group $(\mathrm{p}<0.05)$. On day 15 , ALP activity was the highest in gamma- and deltatocotrienol groups compared to alpha-tocopherol, alphatocotrienol and beta-tocotrienol group $(\mathrm{p}<0.05)$ (Figure 2).

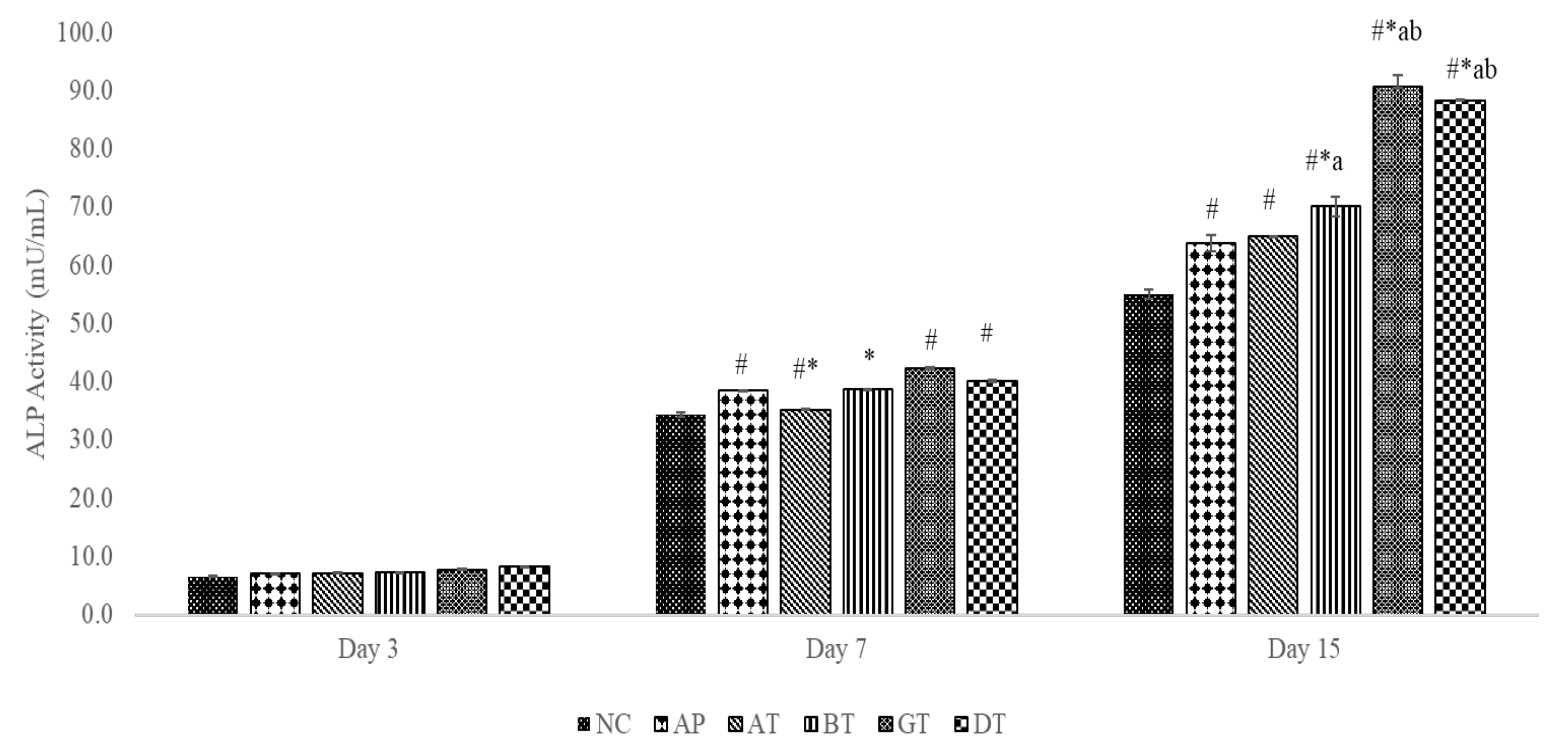

FIGURE 2. ALP activity on day 3, 7 and 15 of incubation with different types of tocotrienol isomers. '\#' indicates a significant difference with vehicle control (NC), '*' with alphatocopherol (AP), 'a' with alpha-tocotrienol (AT) and 'b' with beta-tocotrienol (BT) of the same treatment period. Data are presented as mean $\pm \operatorname{SEM}(n=6$ per group)

\section{OSTEOCALCIN ASSAY}

The osteocalcin level increased significantly with time until day $14(\mathrm{p}<0.05$, significance not marked in Figure $3)$. The osteocalcin level increased significantly in all treatment groups compared to the vehicle control from day 7 to 21. Gamma- and delta-tocotrienol group showed a higher level of osteocalcin than alpha-tocopherol and alpha-tocotrienol group on day 14 . On day 21, the gamma-tocopherol showed the highest osteocalcin level compared to other vitamin $\mathrm{E}$ isomers.

\section{STRUCTURAL HISTOMORPHOMETRY USING VON KOSSA} STAINING

The unseeded undemineralised bone scaffold (PC) showed significantly higher Tb.Th and Tb.N, and lower $\mathrm{Tb}$.Sp compared to seeded (NC) and unseeded demineralised bone $(\mathrm{OB})(\mathrm{p}<0.05)$. The OB bone scaffold also had a significantly lower BV/TV than PC and NC $(p<0.05)$. Bone scaffold treated with gamma- and deltatocotrienol showed significant improvements in BV/ TV and Tb.Th over all the other groups $(p<0.05)$. All 


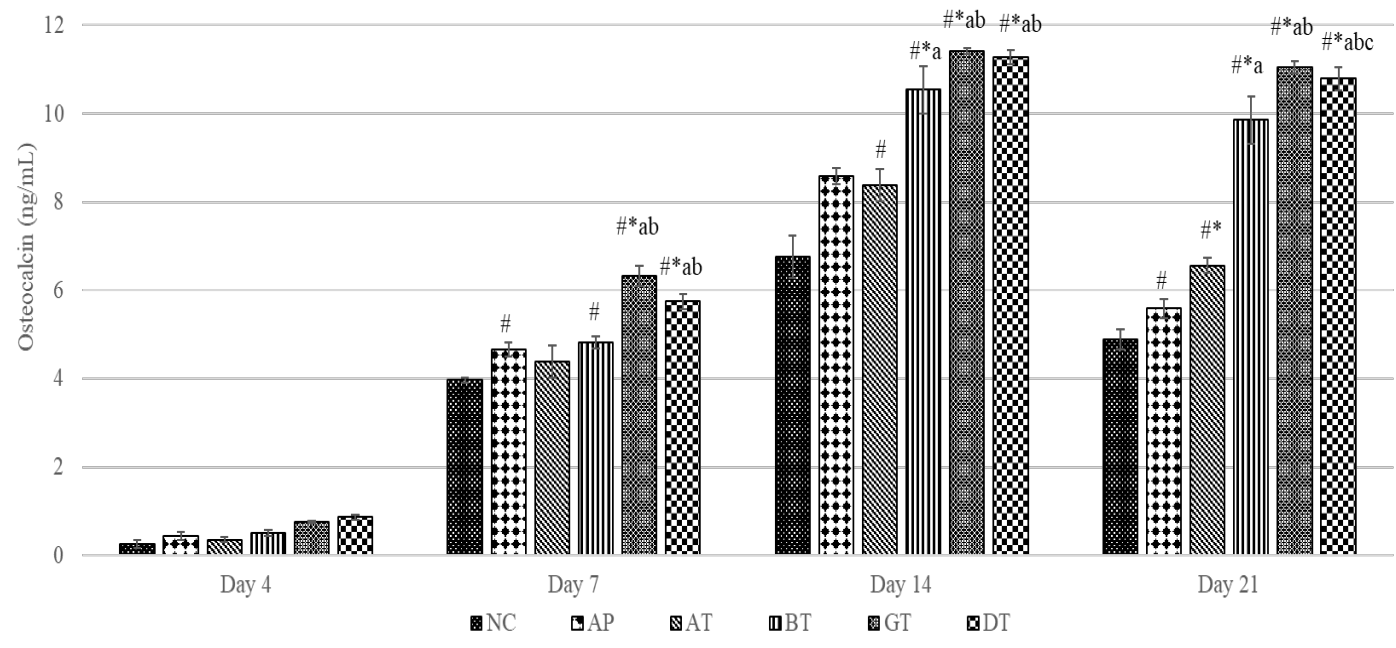

FIGURE 3. Osteocalcin level of hFOB 1.19 cells treated with tocotrienols and alpha-tocopherol. '\#' indicates a significant difference with vehicle control (NC), '*' with alpha-tocopherol (AP), 'a' with alpha-tocotrienol (AT), 'b' with beta-tocotrienol (BT) and 'c' with gamma-tocotrienol (GT) of the same treatment period. Data are presented as mean \pm SEM ( $n=6$ per group)

tocotrienol isomers except delta-tocotrienol increased Tb.N significantly compared to the NC group $(\mathrm{p}<0.05)$. The difference in Tb.N between alpha-tocopherol/delta- tocotrienol and $\mathrm{NC}$ group was not significant ( $\mathrm{p}>0.05$ ). For Tb.Sp, all vitamin $\mathrm{E}$ treatment groups were not significantly different from $\mathrm{NC}$ and $\mathrm{PC}$ group ( $\mathrm{p}>0.05$ ).

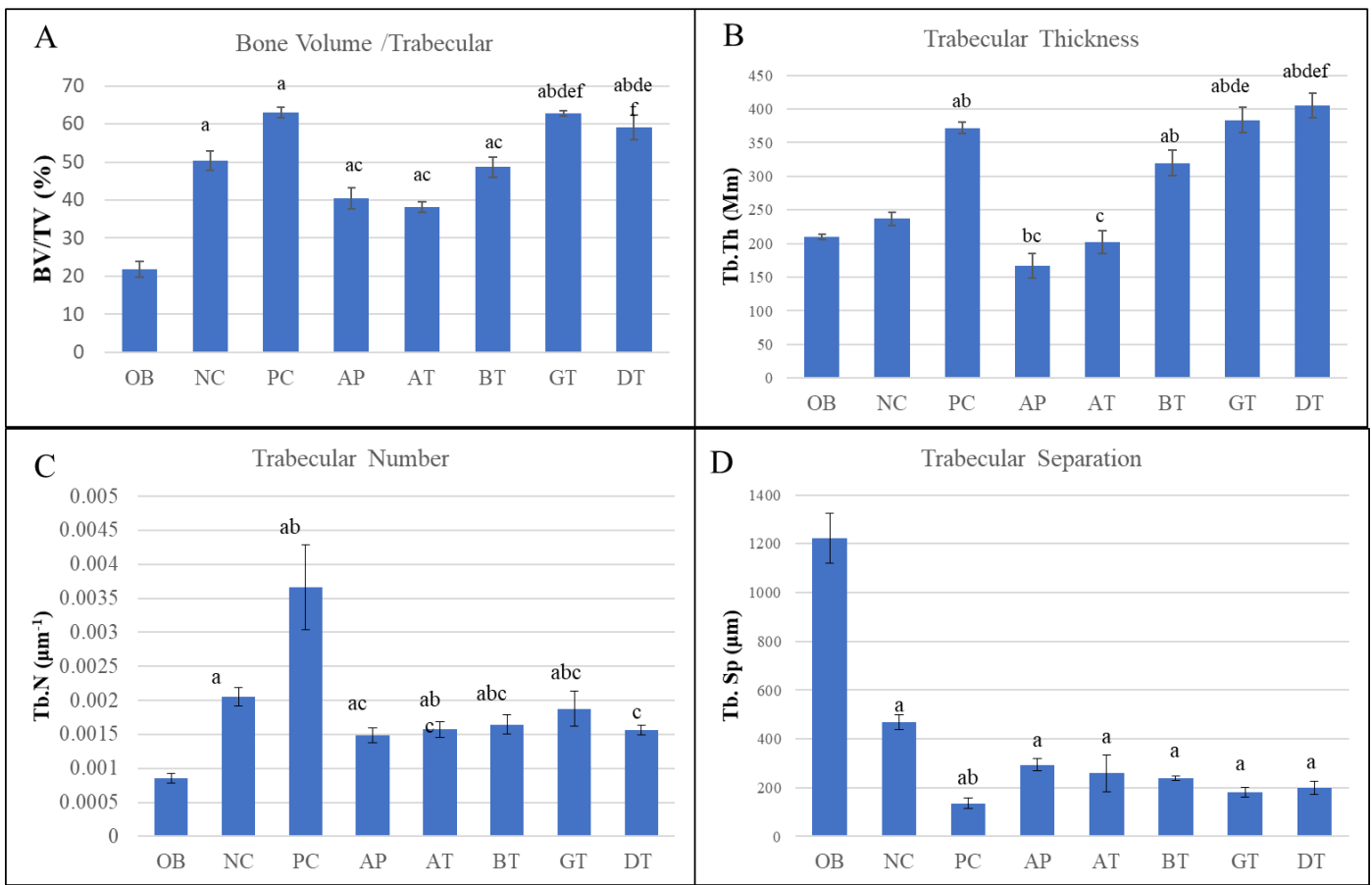

FIGURE 4. Bone histomorphometry on scaffold treated with different isomers of Vitamin E. ' $a$ ' indicates a significant difference with unseeded and demineralised scaffold mimicking osteoporotic bone (OB), 'b' with vehicle control (NC), 'c' with unseeded undemineralised scaffold mimicking normal bone (PC), 'd' with alpha-tocotrienol (AT), 'e' with beta-tocotrienol (BT) and ' $\mathrm{f}$ ' with gamma-tocotrienol (GT). Data are presented as mean \pm SEM ( $\mathrm{n}=6$ per group) 


\section{DISCUSSION}

This study showed that gamma- and delta-tocotrienol significantly promoted the activity of hFOB 1.19 osteoblasts cultured on native bovine scaffold marked by higher ALP activity and osteocalcin expression. The enhanced bone formation activity was translated to higher trabecular thickness and volume in the gamma- and deltatocotrienol treated group. Therefore, gamma- and deltatocotrienol could be the most biologically active vitamin $\mathrm{E}$ isomers on osteoblasts and responsible for the actions of the vitamin E mixture demonstrated in previous animal studies (Chin \& Soelaiman 2014; Chin et al. 2017; Mohamad et al. 2018a, 2018b). hFOB 1.19 osteoblasts of human origin were used because it is more clinically relevant. The osteoblasts were cultured on a bovine bone scaffold to visualize the effects of the isomers directly on skeletal tissue. The native bovine bone scaffold was fully demineralised so that osteoblasts' ability to remineralise it could be tested. The trabecular section was used because it has a high surface to volume ratio for cell adhesion (Hermizi et al. 2009).

Cell viability analysis was conducted to evaluate the optimum concentrations of vitamin $\mathrm{E}$ isomers that are both safe and effective on the osteoblasts. The study results showed that alpha-tocopherol and tocotrienols were not cytotoxic on hFOB 1.19 up to $1000 \mathrm{nM}$. In fact, gamma- dan delta-tocotrienol treatment increased the viability of the cells in a dose-dependent manner. Vitamin E concentration up to $1000 \mathrm{nM}$ was safe and its proliferation-enhancing effects could be observed at a concentration as low as $10 \mathrm{nM}$. In this study, we adopted the concentration of $100 \mathrm{nM}$ for subsequent experiments to ensure anabolic effects of vitamin E could be observed and yet physiologically relevant. A study by Mangialasche et al. (2012) among the elderly population reported that the circulating concentration of total tocotrienol was around $100 \mathrm{nM} / \mathrm{mmol}$ total cholesterol. Previous studies on the safety of tocotrienol on osteoblasts cultured using conventional 2D methods reported a non-toxic range up to $200 \mu \mathrm{M}$ for alpha-tocopherol (Soeta et al. 2010), 8 $\mu \mathrm{M}$ for gamma-tocotrienol (Xu et al. 2018), $25 \mu \mathrm{M}$ for delta-tocotrienol (Shah \& Yeganehjoo 2019), and $1 \mu \mathrm{g}$ for annatto tocotrienol mixture (Wan Hasan et al. 2018). Mazlan et al. (2006) suggested at high concentrations, gamma-tocotrienol might cause toxicity to astrocytes. However, there are two points to be considered. Firstly, the previous studies used different cell types (mostly rodent origin) in their studies, so their optimal concentrations might be different from the current study. Secondly, the concentrations used may be different from the concentrations of vitamin $\mathrm{E}$ isomers in bone tissue because the data available on the distribution of vitamin $\mathrm{E}$ isomers, especially tocotrienols, in bone tissue are very limited.

Alkaline phosphatase is an early marker of osteogenic differentiation secreted by osteoblasts into the ECM. The present study showed an increase in ALP activity for the first 15 days of culture. This result is similar to a study performed by Hermizi et al. (2009), wherein ALP activity of hFOB 1.19 increased with time and peaked on day 12. Other studies reported that ALP expression is higher at the early stage of osteoblast differentiation and marks the onset of mineralization, peaking around day 15-16 in a typical osteoblast culture and decreased upon maturation of osteoblasts (Hermizi et al. 2009; Vozzi et al. 2014; Zhang et al. 2010, 2008). The current study also showed that the increase in ALP activity was more prominent with the tocotrienols isomers, especially in cells treated with gamma- and delta-tocotrienol, indicating their potential in enhancing osteoblast differentiation. This observation corresponds to a previous study on delta-tocotrienol, which showed that it enhanced ALP expression in MC3T3-E1 preosteoblasts, marking their differentiation (Shah \& Yeganehjoo 2019). Another study showed that MC3T3-E1 preosteoblasts treated with annatto tocotrienol mixture $(90 \%$ delta- and $10 \%$ gamma-tocotrienol) showed increased gene expression of ALP (Wan Hasan et al. 2018). In vivo experiment showed that orchidectomised rats treated with annatto tocotrienol mixture for two months showed increased ALP gene expression (Chin \& Soelaiman 2014).

Osteocalcin is the most abundant non-collagenous protein of the mineralised extracellular matrix. Osteocalcin plays a role in matrix mineralization and represents the later stage of osteoblastic differentiation. Osteocalcin is produced by mature osteoblasts during bone formation and acts as a regulator for matrix mineralization (Szulc \& Bauer 2013). In the present study, osteocalcin level increased in a time-dependent manner, peaking on day 15 . This observation was consistent with the finding of Yao et al. (1994), wherein osteocalcin was expressed in the later stage of osteoblast differentiation. The current study also demonstrated that osteocalcin production of the hFOB 1.19 was promoted by treatment with tocotrienol isomers, particularly in the gamma- and delta-tocotrienol treated 
cells, indicating they enhanced osteoblast maturation. This observation is similar to studies performed with MC3T3-E1 cells, which showed that annatto tocotrienol mixture and gamma-tocotrienol increased osteocalcin protein and gene expression in cells (Wan Hasan et al. 2018; Xu et al. 2018).

Bone structural histomorphometry analysis showed that the bone scaffold treated with gamma- and deltatocotrienol increased BV/TV and $\mathrm{Tb}$. Th. It implies that the mature osteoblasts have synthesised matrix onto the scaffold and mineralised them. Since this is the first time the effects of tocotrienols and alpha-tocopherols were tested on bone cells cultured on a bone scaffold, comparisons are drawn with previous in vivo studies. Shuid et al. (2010) reported that gamma-tocotrienol improved bone structural histomorphometric parameters of normal adult male rats and their anabolic effects were more potent than the alpha-tocopherol at the same dose. In this study, $\mathrm{Tb} . \mathrm{Sp}$ of all bone scaffold treated with tocotrienols and alpha-tocopherol were significantly reduced as compared to OB. This observation is contributed by increased BV/ $\mathrm{TV}, \mathrm{Tb} . \mathrm{Th}$ and TB.N attributed probably to enhanced bone formation, which reduces the empty spaces between trabeculae.

Another study by Hermizi et al. (2009) using a nicotine-induced osteoporosis rat model showed that gamma-tocotrienol could reverse trabecular thickness and number better than alpha-tocopherol or tocotrienol mixture. Annatto tocotrienol also improved bone histomorphometric indices in rats deprived of androgen (Chin \& Soelaiman 2014; Mohamad et al. 2018b) and oestrogen (Abdul-Majeed et al. 2015). The findings of the present study indicated that gamma- and delta-tocotrienol might be responsible for most of the actions in preserving bone microarchitecture in animal studies, by driving differentiation and bone formation activity of osteoblasts. This observation is also coherent with previous studies using gamma- and annatto tocotrienol on osteoblasts cultured using conventional two-dimensional methods, which found increased calcium nodule formation in culture (Wan Hasan et al. 2018; Xu et al. 2018).

The current study is a pilot study investigating the bone anabolic action of vitamin E, particularly tocotrienol. A more in-depth investigation of the molecular mechanisms of these vitamin $\mathrm{E}$ isomers in promoting osteoblast differentiation and anabolic actions should be investigated in the future. Some of the reported mechanisms of vitamin $\mathrm{E}$ in bone protection include antioxidant, anti-inflammatory, mevalonate suppressive and generegulating effects (Chin et al. 2013). The current study benefits from the use of a 3D culture system, which enables the effect on the bone tissue to be directly visualised. However, the 3D culture system could perform better with the aid of a bioreactor to ensure the adequate supply of nutrients throughout the scaffolds and homogenous distribution of cells (Martin et al. 2004). Since we were interested only in the action of vitamin $\mathrm{E}$ on osteoblasts in this study, osteoclasts were not cultured on the scaffolds together with osteoblasts. This approach will be considered in future studies to study the influence of vitamin $\mathrm{E}$ on bone cell dynamics as it is more physiologically similar to the in vivo skeletal microenvironment system.

\section{CONCLUSION}

Gamma- and delta-tocotrienol are the most potent tocotrienol isomers driving differentiation of osteoblasts and bone formation, as evidenced by enhanced ALP activity, higher osteocalcin level and improved bone structural indices of the scaffold. Their effects are stronger than alpha-tocopherol based on these indices. Thus, gamma- and delta-tocotrienol may contribute to the bone anabolic effects of vitamin $\mathrm{E}$ mixture previously observed in animal studies. Further investigation of the molecular action of vitamin $\mathrm{E}$ isomers should be performed to explain their anabolic actions. The idea of utilising bone scaffold infused with vitamin $\mathrm{E}$ isomers like gamma and delta-tocotrienol may have future orthopaedic application.

\section{ACKNOWLEDGEMENTS}

This work was fully funded by grant Laureate-2017-003 provided by Universiti Kebangsaan Malaysia and FRGS/1/2018/SKK10/UKM/03/1 provided by the Ministry of Higher Education, Malaysia. We thank American Rivers Inc. for sponsoring tocotrienol isomers in this study. The authors would also like to thank Mrs Nurul Hafizah Abas, Mrs Nur Sabariah Adnan and Mr Mohd Mustazil Mohd Noor for their technical assistance throughout the project. No conflict of interest exists for all authors.

\section{REFERENCES}

Abdullah, A.R., Hapidin, H. \& Abdullah, H. 2018. The role of semipurified fractions isolated from Quercus infectoria on bone metabolism by using hFOB 1.19 human fetal 
osteoblast cell model. Evidence-based Complementary and Alternative Medicine 2018: 5319528.

Abdul-Majeed, S., Mohamed, N. \& Soelaiman, I.N. 2015. The use of delta-tocotrienol and lovastatin for anti-osteoporotic therapy. Life Sciences 125: 42-48.

Cejka, D., Benesch, T., Krestan, C., Roschger, P., Klaushofer, K., Pietschmann, P. \& Haas, M. 2008. Effect of teriparatide on early bone loss after kidney transplantation. American Journal of Transplantation 8(9): 1864-1870.

Chin, K.Y. \& Soelaiman, I.N. 2019. The role of tocotrienol in preventing male osteoporosis - A review of current evidence. International Journal of Molecular Sciences 20(6): 13551374.

Chin, K.Y. \& Soelaiman, I.N. 2015. The biological effects of tocotrienol on bone: A review on evidence from rodent models. Drug Design, Development and Therapy 9: 20492061.

Chin, K.Y. \& Soelaiman, I.N. 2014. Effects of annatto-derived tocotrienol supplementation on osteoporosis induced by testosterone deficiency in rats. Clinical Intervention in Aging 9: 1247-1259.

Chin, K.Y., Abdul-Majeed, S., Mohamed, N. \& Soelaiman, I.N. 2017. The effects of tocotrienol and lovastatin cosupplementation on bone dynamic histomorphometry and bone morphogenetic protein-2 expression in rats with estrogen deficiency. Nutrients 9(2): 143-154.

Chin, K.Y., Mo, H. \& Soelaiman, I.N. 2013. A review of the possible mechanisms of action of tocotrienol - A potential antiosteoporotic agent. Current Drug Targets 14(13): 15331541.

Chiu, Y.C., Larson, J.C., Isom, A. \& Brey, E.M. 2010. Generation of porous poly(ethylene glycol) hydrogels by salt leaching. Tissue Engineering Part C: Methods 16(5): 905912.

Chun, J., Lee, J., Ye, L., Exler, J. \& Eitenmiller, R.R. 2006. Tocopherol and tocotrienol contents of raw and processed fruits and vegetables in the United States diet. Journal of Food Composition and Analysis 19(2-3): 196-204.

Daud, Z.A., Tubie, B., Sheyman, M., Osia, R., Adams, J., Tubie, S. \& Khosla, P. 2013. Vitamin E tocotrienol supplementation improves lipid profiles in chronic hemodialysis patients. Vascular Health and Risk Management 9(1): 747-761.

Eiselt, P., Yeh, J., Latvala, R.K., Shea, L.D. \& Mooney, D.J. 2000. Porous carriers for biomedical applications based on alginate hydrogels. Biomaterials 21(19): 1921-1927.

Feresin, R.G., Johnson, S.A., Elam, M.L., Kim, J.S., Khalil, D.A., Lucas, E.A., Smith, B.J., Payton, M.E., Akhter, M.P. \& Arjmandi, B.H. 2013. Effects of vitamin E on bone biomechanical and histomorphometric parameters in ovariectomized rats. Journal of Osteoporosis 2013: 825985.

Finkelstein, J.S., Wyland, J.J., Lee, H. \& Neer, R.M. 2010. Effects of teriparatide, alendronate, or both in women with postmenopausal osteoporosis. The Journal of Clinical Endocrinology and Metabolism 95(4): 1838-1845.

Hermizi, H., Faizah, O., Soelaiman, I.N., Ahmad Nazrun, S. \& Norazlina, M. 2009. Beneficial effects of tocotrienol and tocopherol on bone histomorphometric parameters in Sprague-Dawley male rats after nicotine cessation. Calcified Tissue International 84(1): 65-74.

Leclerc, E., David, B., Griscom, L., Lepioufle, B., Fujii, T., Layrolle, P. \& Legallaisa, C. 2006. Study of osteoblastic cells in a microfluidic environment. Biomaterials 27(4): 586-595.

Mangialasche, F., Xu, W., Kivipelto, M., Costanzi, E., Ercolani, S., Pigliautile, M., Cecchetti, R., Baglioni, M., Simmons, A., Soininen, H., Tsolaki, M., Kloszewska, I., Vellas, B., Lovestone, S. \& Mecocci, P. 2012. Tocopherols and tocotrienols plasma levels are associated with cognitive impairment. Neurobiology of Aging 33(10): 2282-2290.

Martin, I., Wendt, D. \& Heberer, M. 2004. The role of bioreactors in tissue engineering. Trends in Biotechnology 22(2): 80-86.

Mazlan, M., Then, S.M., Mat Top, G. \& Zurinah Wan Ngah, W. 2006. Comparative effects of $\alpha$-tocopherol and $\gamma$-tocotrienol against hydrogen peroxide induced apoptosis on primarycultured astrocytes. Journal of the Neurological Science 243(1-2): 5-12.

Mohamad, N.V., Soelaiman, I.N. \& Chin, K.Y. 2018a. Effect of tocotrienol from Bixa orellana (annatto) on bone microstructure, calcium content, and biomechanical strength in a model of male osteoporosis induced by buserelin. Drug Design, Development and Therapy 12: 555-564.

Mohamad, N.V., Soelaiman, I.N. \& Chin, K.Y. 2018b. Effects of tocotrienol from Bixa orellana (annatto) on bone histomorphometry in a male osteoporosis model induced by buserelin. Biomedicine \& Pharmacotherapy 103: 453462.

Motamedian, S.R., Hosseinpour, S., Ahsaie, M.G. \& Khojasteh, A. 2015. Smart scaffolds in bone tissue engineering: A systematic review of literature. World Journal of Stem Cells 7(3): 657-668.

Pavone, V., Testa, G., Giardina, S.M.C., Vescio, A., Restivo, D.A. \& Sessa, G. 2017. Pharmacological therapy of osteoporosis: A systematic current review of literature. Frontiers in Pharmacology 8(803): 1-7.

Roux, S. \& Orcel, P. 2000. Bone loss. Factors that regulate osteoclast differentiation: An update. Arthritis Research \& Therapy 2(6): 451-456.

Sen, C.K., Rink, C. \& Khanna, S. 2010. Palm oil-derived natural vitamin $\mathrm{E}$ alpha-tocotrienol in brain health and disease. Journal of the American College of Nutrition 29(3): 314-323.

Shah, A.K. \& Yeganehjoo, H. 2019. The stimulatory impact of $d-\delta$-tocotrienol on the differentiation of murine 
MC3T3-E1 preosteoblasts. Molecular and Cellular Biochemistry 462(1-2): 173-183.

Shahabipour, F., Mahdavi-Shahri, N., Matin, M.M., Tavassoli, A. \& Zebarjad, S.M. 2013. Scaffolds derived from cancellous bovine bone support mesenchymal stem cells' maintenance and growth. In Vitro Cellular \& Developmental Biology - Animal 49(6): 440-448.

Shen, C.L., Klein, A., Chin, K.Y., Mo, H., Tsai, P., Yang, R.S., Chyu, M.C. \& Soelaiman, I.N. 2017. Tocotrienols for bone health: A translational approach. Annals of the New York Academy of Sciences 1401(1): 150-165.

Shuid, A.N., Mehat, Z., Mohamed, N., Muhammad, N. \& Soelaiman, I.N. 2010. Vitamin E exhibits bone anabolic actions in normal male rats. Journal of Bone and Mineral Metabolism 28(2): 149-156.

Soeta, S., Higuchi, M., Yoshimura, I., Itoh, R., Kimura, N. \& Aamsaki, H. 2010. Effects of vitamin E on the osteoblast differentiation. Journal of Veterinary Medical Science 72(7): 951-957.

Szulc, P. \& Bauer, D.C. 2013. Biochemical markers of bone turnover in osteoporosis. In Osteoporosis. 4th ed., edited by Marcus, R., Feldman, D., Dempster, D.W., Luckey, M. \& Cauley, J.A. San Diego: Academic Press. pp. 1573-1610.

Vasanthi, H.R., Parameswari, R.P. \& Das, D.K. 2012. Multifaceted role of tocotrienols in cardioprotection supports their structure: function relation. Genes \& Nutrition 7(1): $19-28$

Vozzi, G., Corallo, C., Carta, S., Fortina, M., Gattazzo, F., Galletti, M. \& Giordano, N. 2014. Collagen-gelatingenipin-hydroxyapatite composite scaffolds colonized by human primary osteoblasts are suitable for bone tissue engineering applications: in vitro evidences. Journal of Biomedical Materials Research Part A 102(5): 14151421.

Wan Hasan, W.N., Chin, K.Y., Abd Ghafar, N. \& Soelaiman, I.N. 2020. Annatto-derived tocotrienol promotes mineralization of MC3T3-E1 cells by enhancing BMP2 protein expression via inhibiting RhoA Activation and HMG-CoA reductase gene expression. Drug Design, Development and Therapy 14: 969-976.

Wan Hasan, W.N., Abd Ghafar, N., Chin, K.Y. \& Soelaiman, I.N. 2018. Annatto-derived tocotrienol stimulates osteogenic activity in preosteoblastic MC3T3-E1 cells: A temporal sequential study. Drug Design, Development and Therapy 12: 1715-1726.

Wang, X., Schröder, H.C., Wiens, M., Ushijima, H. \& Müller, W.E. 2012. Bio-silica and bio-polyphosphate: Applications in biomedicine (bone formation). Current Opinion in Biotechnology 23(4): 570-578.

Wong, S.K., Kamisah, Y., Mohamed, N., Muhammad, N., Masbah, N., Fahami, N.A.M., Mohamed, I.N., Shuid, A.N., Saad, Q.M., Abdullah, A., Mohamad, N.V., Ibrahim, N.I., Pang, K.L., Chow, Y.Y., Thong, B.K.S., Subramaniam, S., Chan, C.Y., Soelaiman, I.N. \& Chin, K.Y. 2020. Potential role of tocotrienols on non-communicable diseases: A review of current evidence. Nutrients 12(1): 259-342.
Wong, S.K., Mohamad, N.V., Ibrahim, N., Chin, K.Y., Shuid, A.N. \& Soelaiman, I.N. 2019. The molecular mechanism of vitamin $\mathrm{E}$ as a bone-protecting agent: A review on current evidence. International Journal of Molecular Sciences 20(6): 1453-1478.

Xu, W., He, P., He, S., Cui, P., Mi, Y., Yang, Y., Li, Y. \& Zhou, S. 2018. Gamma-tocotrienol stimulates the proliferation, differentiation, and mineralization in osteoblastic MC3T3-E1 cells. Journal of Chemistry 2018: 3805932.

Yao, K.L., Todescan Jr., R. \& Sodek, J. 1994. Temporal changes in matrix protein synthesis and mRNA expression during mineralized tissue formation by adult rat bone marrow cells in culture. Journal of Bone and Mineral Research 9(2): 231-240.

Zhang, Y., Venugopal, J.R., Wong, S., Li, X., Su, B., Ramakrishna, S. \& Lim, C.T. 2010. Enhanced biomineralization in osteoblasts on a novel electrospun biocomposite nanofibrous substrate of hydroxyapatite/ collagen/chitosan. Tissue Engineering Part A 16(6): 19491960.

Zhang, Y., Venugopal, J.R., El-Turki, A., Ramakrishna, S., Su, B. \& Lim, C.T. 2008. Electrospun biomimetic nanocomposite nanofibers of hydroxyapatite/chitosan for bone tissue engineering. Biomaterials 29(32): 4314-4322.

Nur Farhana Mohd Fozi, James Jam Jolly, Chin Kok Yong \& Ima Nirwana Soelaiman*

Department of Pharmacology

Faculty of Medicine

Universiti Kebangsaan Malaysia

Jalan Yaacob Latif, Bandar Tun Razak

56000 Cheras, Kuala Lumpur, Federal Territory

Malaysia

Chua Kien Hui

Department of Physiology

Faculty of Medicine

Universiti Kebangsaan Malaysia

Jalan Yaacob Latif, Bandar Tun Razak

56000 Cheras, Kuala Lumpur, Federal Territory

Malaysia

Ekram Alias

Department of Biochemistry

Faculty of Medicine

Universiti Kebangsaan Malaysia

Jalan Yaacob Latif, Bandar Tun Razak

56000 Cheras, Kuala Lumpur, Federal Territory

Malaysia

*Corresponding author; email: imasoel@ppukm.ukm.edu.my

Received: 3 April 2020

Accepted: 9 December 2020 